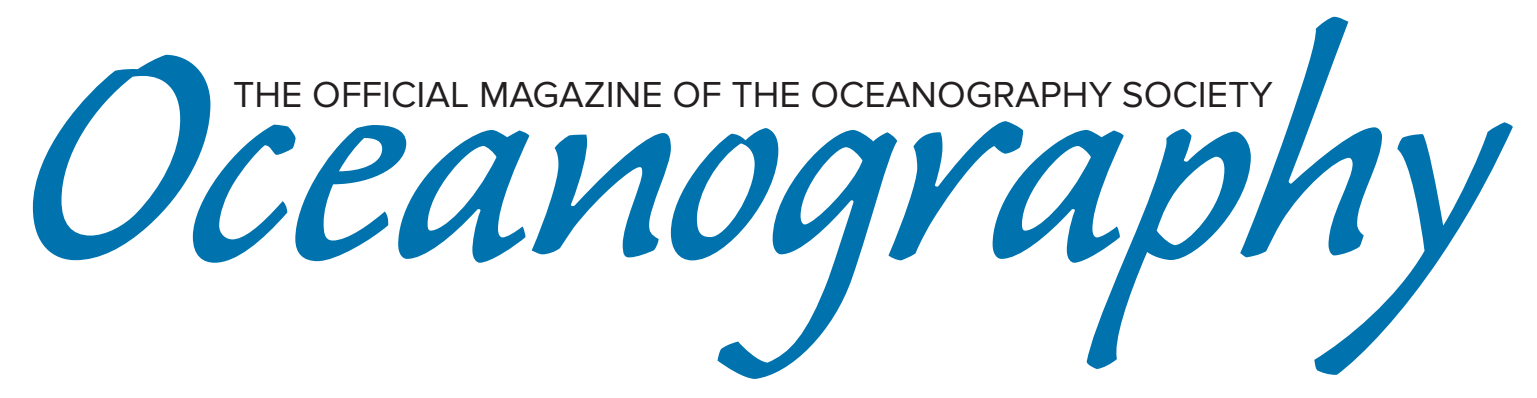

CITATION

Briscoe, M. 2017. Thank you, Walter Munk, for being there at the beginning.

Oceanography 30(4):8, https://doi.org/10.5670/oceanog.2017.402.

$\mathrm{DOI}$

https://doi.org/10.5670/oceanog.2017.402

COPYRIGHT

This article has been published in Oceanography, Volume 30, Number 4, a quarterly journal of The Oceanography Society. Copyright 2017 by The Oceanography Society. All rights reserved.

USAGE

Permission is granted to copy this article for use in teaching and research. Republication, systematic reproduction, or collective redistribution of any portion of this article by photocopy machine, reposting, or other means is permitted only with the approval of The Oceanography Society. Send all correspondence to: info@tos.org or The Oceanography Society, PO Box 1931, Rockville, MD 20849-1931, USA. 


\section{Thank You, Walter Munk, for Being There at the Beginning вy Mel Briscoe}

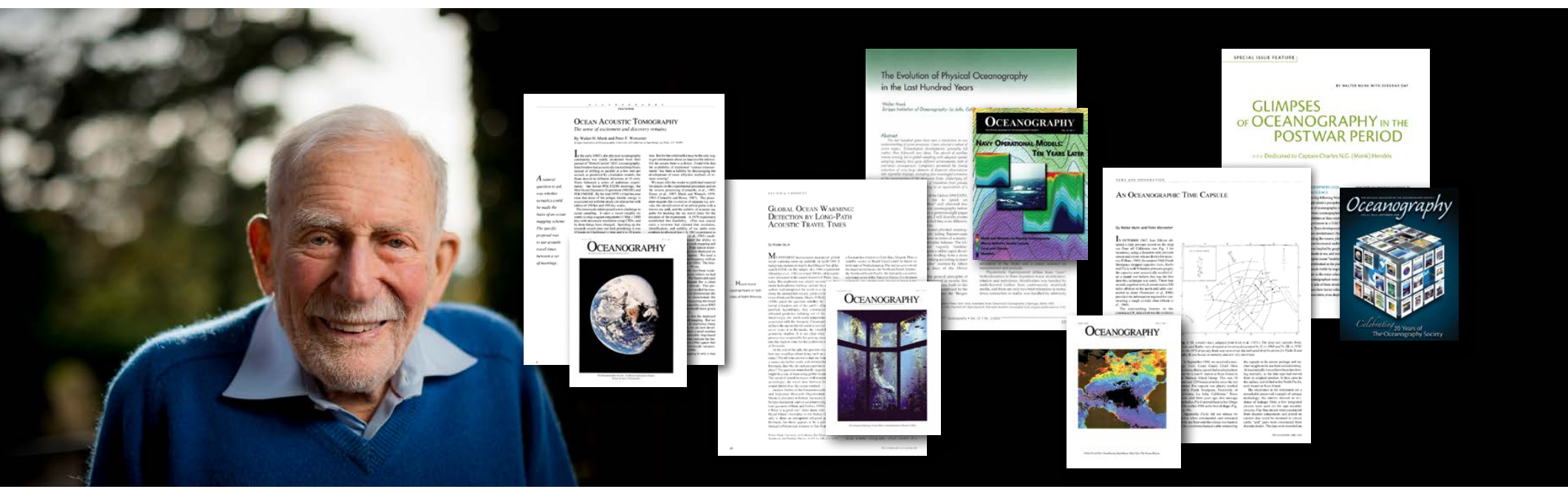

Photo by Erik Jepsen/UC San Diego Publications

Walter Munk turned 100 on October 19, 2017. I first met Walter almost half a century ago, when I was a young scientist working in Europe, and was in the process of changing my focus from fluid mechanics to physical oceanography. At that time, an older European colleague told me that there were just two real oceanographers in the United States: Henry Stommel and Walter Munk. Over the past 50 years, I've had the satisfaction of working down the hallway from Henry (at Woods Hole Oceanographic Institution), and of having contact with Walter on a fair number of occasions. In addition to being a gregarious and engaging gentleman, Walter has been an inspiring and enthusiastic colleague to many of us, and a formative presence to more than a few.

Walter played an important role in the creation of The Oceanography Society. His eclectic approach to oceanography and his penchant for speaking and writing simply, directly, and clearly so that many, rather than just a few, could understand him were already legendary-and inspired the mission of Oceanography magazine. In our initial inquiries to colleagues in 1987 prior to forming TOS, Walter was encouraging about the Society's goals and structure. In his closing remarks at the Inaugural Meeting of TOS in 1989, he commented, "It is time for the oceanographic disciplines to come together. It is time for an Oceanography Society." His full remarks are in Oceanography, volume 2, number 2 (https://doi.org/10.5670/oceanog.1989.19); that issue also contains his initial article about the Heard Island Experiment (https://doi.org/10.5670/oceanog.1989.10), which is a long story in and of itself. (I worked closely with Walter through the Heard Island years, and we both learned a lot about whales.) The 1989 article was Walter's second in Oceanography; his first was in volume 1 , number 1 , on ocean acoustic tomography (https://doi.org/10.5670/oceanog.1988.31). Over the years, Walter has authored 14 submissions to Oceanography and has been mentioned in the magazine over 200 times. Articles written by or mentioning Walter now have more than 350,000 hits on Google. And he is still working, on wind waves as it turns out, a fitting return to one of his early successes: predicting the wave conditions for the D-Day invasion of Normandy.

Walter is a strikingly gracious gentleman who has had an enormous positive impact on our science and on the people he has encountered, myself included. A recent biography and tribute that appeared in 2016 in Acoustics Today (Volume 12, pages 36-42) provides more context for these statements; no need to repeat them here. Those of us working in oceanography today are fortunate to have his personality and his intellect as part of our culture. And TOS is fortunate to have had his sincere and continuing interest in the success of our Society. Carry on, Walter! ®

\section{AUTHOR}

Mel Briscoe (mel@oceangeeks.com) is President, OceanGeeks LLC, Alexandria, VA, USA.

\section{ARTICLE CITATION}

Briscoe, M. 2017. Thank you, Walter Munk, for being there at the beginning Oceanography 30(4):8, https://doi.org/10.5670/oceanog.2017.402. 